The Call from Algeria 



\title{
The Call from Algeria
}

Third Worldism, Revolution, and the Turn to Islam

\author{
Robert Malley
}


University of California Press

Berkeley and Los Angeles, California

University of California Press, Ltd.

London, England

(C) 1996 by

The Regents of the University of California

Library of Congress Cataloging-in-Publication Data

Malley, Robert, I963-

The call from Algeria : third worldism, revolution, and the turn to Islam / Robert Malley.

p. $\mathrm{cm}$.

Includes bibliographic references and index.

ISBN 0-520-20300-3 (alk. paper). -ISBN 0-520-203OI-r (pbk. : alk. paper)

I. Algeria - Politics and government. 2. Developing countries-Miscellanea. I. Title.

DT295.5.M34 1996

$965.05-\mathrm{dc} 20$

$95-36054$

CIP

Printed in the United States of America

$\begin{array}{lllllllll}9 & 8 & 7 & 6 & 5 & 4 & 3 & 2 & 1\end{array}$

The paper used in this publication meets the minimum requirements of American National Standard for Information Sciences - Permanence of Paper for Printed Library Materials, ANSI Z39.48-1984. 
A Gemma

Omunque tu sia 
